\title{
Effect of NO2 and water on the catalytic oxidation of soot
}

\author{
Christensen, Jakob Munkholt; Grunwaldt, Jan-Dierk; Jensen, Anker Degn
}

Published in:

Applied Catalysis B: Environmental

Link to article, DOI:

10.1016/j.apcatb.2016.12.024

Publication date:

2017

Document Version

Peer reviewed version

Link back to DTU Orbit

Citation (APA):

Christensen, J. M., Grunwaldt, J-D., \& Jensen, A. D. (2017). Effect of NO2 and water on the catalytic oxidation of soot. Applied Catalysis B: Environmental, 205, 182-188. https://doi.org/10.1016/j.apcatb.2016.12.024

\section{General rights}

Copyright and moral rights for the publications made accessible in the public portal are retained by the authors and/or other copyright owners and it is a condition of accessing publications that users recognise and abide by the legal requirements associated with these rights.

- Users may download and print one copy of any publication from the public portal for the purpose of private study or research.

- You may not further distribute the material or use it for any profit-making activity or commercial gain

- You may freely distribute the URL identifying the publication in the public portal 


\title{
Effect of $\mathrm{NO}_{2}$ and water on the catalytic oxidation of soot
}

\author{
Jakob M. Christensen $^{1^{*}}$, Jan-Dierk Grunwaldt ${ }^{1,2}$ and Anker D. Jensen ${ }^{1}$ \\ ${ }^{1}$ Department of Chemical and Biochemical Engineering, Technical University of Denmark, Søltofts
}

Plads B229, 2800 Kgs. Lyngby (Denmark)

${ }^{2}$ Institute for Chemical Technology and Polymer Chemistry (ITCP), Karlsruhe Institute of

Technology, Engesserstrasse 20, 76131 Karlsruhe (Germany)

*Corresponding author: jmc@kt.dtu.dk

\begin{abstract}
It has been investigated how the addition of $\mathrm{NO}_{2}$ to $10 \mathrm{vol} \% \mathrm{O}_{2} / \mathrm{N}_{2}$ influences non-catalytic soot oxidation and soot oxidation in intimate or loose contact with a catalyst. In non-catalytic soot oxidation the oxidation rate is increased significantly at lower temperatures by $\mathrm{NO}_{2}$. For soot oxidation in tight contact with a $\mathrm{Co}_{3} \mathrm{O}_{4}$ catalyst a more reactive $\mathrm{NO}_{2}$-containg atmosphere did not change the oxidation profile significantly during temperature programmed oxidation. This is consistent with the expected Mars van Krevelen mechanism, where the rate limiting step is reaction between carbon and oxide, and where the reaction thus has reached the 0 . order regime in the gaseous reactant. In loose contact with a catalyst the presence of $\mathrm{NO}_{2}$ causes a pronounced enhancement of the oxidation rate. The rate constants for loose contact soot oxidation in the presence of $\mathrm{NO}_{2}$ exhibited a volcano-curve dependence on the heat of oxygen chemisorption, and among the tested pure metals and oxides $\mathrm{Cr}_{2} \mathrm{O}_{3}$ was the most active catalyst. Further improvements were achieved with a $\mathrm{Fe}_{\mathrm{a}} \mathrm{Cr}_{\mathrm{b}} \mathrm{O}_{\mathrm{x}}$ binary oxide catalyst.
\end{abstract}

Keywords: Soot oxidation, Nitrogen dioxide, Mars van Krevelen mechanism, Volcano curve, Spillover. 


\section{Introduction}

Soot particles in the exhaust from diesel vehicles adversely affect human health [1-3], and are therefore typically removed from the exhaust gas by filtration through a ceramic filter [4-6]. As the filter becomes blocked by the soot particles, periodic regeneration is necessary. For this purpose the filter temperature is increased, and the soot is oxidized. The growing back pressure due to the soot deposits and the temperature increase required for filter regeneration are associated with increased fuel consumption [7], and it is desirable to develop improved soot oxidation catalysts that can lower the regeneration temperature [4]. Being a gas/solid/solid interaction, where the contact between soot and catalyst is very important, the catalytic effect depends strongly on the intimacy of mixing between soot and catalyst [8, 9]. In laboratory tests, where soot and catalyst are crushed together (so-called tight contact), the oxidation occurs at a significantly lower temperature (typically 100$200{ }^{\circ} \mathrm{C}$ ), than if soot and catalyst are mixed together gently (so-called loose contact) [8, 9]. In tight contact an extensive interface between the primary particles of soot and catalyst is established, but in loose contact the interface is limited to isolated contact points between larger clusters of the primary particles [10]. A number of filtration experiments have shown indications of reactivity corresponding to both contact types [11-17]. It therefore seems likely that both types of contact would be relevant for real filter applications.

To enable the development of improved soot oxidation catalysts the factors that determine the catalytic activity need to be identified. As expected the surface area of the employed catalyst is important $[18,19]$, and the strength of the oxygen-catalyst bond, as measured by the heat of oxygen chemisorption, is also very important for the catalytic activity [20]. For both tight and loose contact tests with $\mathrm{O}_{2}$ as the oxidant the rate constants for various metal or metal oxide catalysts resulted in a 
volcano curve if plotted as function of the heat of oxygen chemisorption for the catalytic materials [20]. In tight contact materials such as $\mathrm{Co}_{3} \mathrm{O}_{4}$ and $\mathrm{CeO}_{2}$ that bind oxygen more weakly were found to be nearest to the optimal bond strength, while the more strongly binding $\mathrm{Cr}_{2} \mathrm{O}_{3}$ was nearest to the activity optimum in loose contact [20]. The shift in the optimal material may reflect the existence of multiple reaction pathways that contribute with different relative weight in the two cases. In tight contact tests TEM studies [21, 22], isotopic labeling studies [23-28] and XPS studies [29] have indicated that the oxidation primarily occurs at the soot/catalyst interface by a Mars van Krevelen [30] mechanism, namely an initial oxidation by catalyst lattice oxygen followed by re-oxidation of the catalyst. The rate limiting step is most likely the reaction of lattice oxygen with carbon, since the reaction rate depends on both the oxygen bond strength of the catalyst [20] and the inherent reactivity of the soot [19]. In loose contact tests the activation of oxygen occurs on the oxide [28, 31-34], and most likely the activated oxygen then diffuses to the soot [35-37], and reacts at the most reactive defect sites $[38,39]$. A catalytic effect is also present in experiments where soot and catalyst are separated by an inert (and insulating) material that the activated oxygen must pass to reach the soot $[32,36]$, and it therefore seems likely that the oxygen activation is by dissociative chemisorption into atomic oxygen that would remain reactive [40] also when removed from the catalyst surface.

The absolute rate of soot oxidation will also depend on the gas atmosphere [41-43]. The example of greatest practical importance is that many filter regeneration strategies for diesel vehicles involve acceleration of the soot oxidation by catalytically oxidizing $\mathrm{NO}$ in the exhaust gas to $\mathrm{NO}_{2}$ [44-46], which is a more reactive oxidant than $\mathrm{O}_{2}$ [46-50]. There are known examples, where the volcano curve for a catalytic reaction, and thus the optimal choice of catalyst, is shifted depending on the gas atmosphere $[51,52]$. It is therefore relevant to evaluate, how the components in the gas atmosphere, particularly $\mathrm{NO}_{2}$, influence the catalytic reaction and optimal choice of catalyst, also as 
a function of the contact between soot and catalyst. This is the topic of the present paper.

Additionally, this work provides global kinetic parameters for the occurring oxidation reactions, which may be of use for CFD-based models of soot combustion dynamics in catalytic diesel particulate filters [53, 54].

\section{Experimental}

\subsection{Catalysts used for screening experiments}

The catalysts used in the screening studies were the bulk oxides or metals also used in our previous study, where the identities of the catalysts were confirmed by XRD [20]. In the cases of $\gamma-\mathrm{Fe}_{2} \mathrm{O}_{3}, \mathrm{Pd}$ and Pt commercially acquired samples from Sigma-Aldrich were used. In the cases of $\mathrm{CeO}_{2}, \mathrm{Co}_{3} \mathrm{O}_{4}$, $\mathrm{MnO}_{\mathrm{x}}, \mathrm{ZnO}$ and $\mathrm{Cr}_{2} \mathrm{O}_{3}$ the oxide samples were prepared by flame spray pyrolysis according to the method described elsewhere [19, 20].

2.2 $\mathrm{SiO}_{2}$ supported $\mathrm{FeCr}_{2} \mathrm{O}_{x}$ binary oxide catalyst

An $\mathrm{SiO}_{2}$ supported $\mathrm{FeCr}_{2} \mathrm{O}_{\mathrm{x}}$ catalysts also employed in our previous study [20] was used. $\mathrm{SiO}_{2}$ extrudates (Saint-Gobain, $250 \mathrm{~m}^{2} / \mathrm{g}$ ) were impregnated with an aqueous solution of $\mathrm{Fe}\left(\mathrm{NO}_{3}\right)_{3} \cdot 9 \mathrm{H}_{2} \mathrm{O}$ and $\mathrm{Cr}\left(\mathrm{NO}_{3}\right)_{3} \cdot 9 \mathrm{H}_{2} \mathrm{O}$ (Sigma Aldrich) to produce $\mathrm{FeCr}_{2} \mathrm{O}_{\mathrm{x}} / \mathrm{SiO}_{2}$ with a total metal loading of 14.8 $\mathrm{wt} \%$. The impregnated sample was aged for $2 \mathrm{~h}$ and then dried at $110^{\circ} \mathrm{C}$ overnight. The dried catalyst precursor was then calcined in stagnant air for $2 \mathrm{~h}$ at $500{ }^{\circ} \mathrm{C}$ (ramp: $20^{\circ} \mathrm{C} / \mathrm{min}$ ). Finally the 
calcined catalyst was crushed to $<300 \mu \mathrm{m}$ and used in the powdered form. The XRD pattern of the catalyst contains the reflections from $\alpha-\mathrm{Cr}_{2} \mathrm{O}_{3}$ shifted slightly downwards towards the reflections from $\alpha-\mathrm{Fe}_{2} \mathrm{O}_{3}$ suggesting the formation of a mixed oxide [20].

\subsection{Catalytic soot oxidation}

The catalytic activity in soot oxidation was measured using a flow reactor setup described elsewhere [20]. For the activity tests soot ( 2 mg, NIST SRM 2975) and catalyst in a ratio of 1:5 (wt:wt) were stirred together with a spatula (loose contact) or crushed together for 6 minutes in an agate mortar (tight contact). The silica supported Fe-Cr binary oxide catalyst was tested at a higher soot:catalyst ratio of 1:10 (wt:wt) due to the lower fraction (15 wt\%) of active material in this sample. The soot/catalyst mixture was transferred to a $7 \mathrm{~cm}$ long, $1 \mathrm{~cm}$ wide alumina sample holder, which was placed in the center of a quartz tube (length: $65 \mathrm{~cm}$, inner diameter: $24 \mathrm{~mm}$ ) within a horizontal, tubular furnace. The sample was then subjected to a $1 \mathrm{NL} / \mathrm{min}$ flow of $10.2 \mathrm{vol} \% \mathrm{O}_{2}$ in $\mathrm{N}_{2}$ (in some cases the feed also contained $934 \mathrm{ppmv} \mathrm{NO}_{2}$ or $887 \mathrm{ppmv} \mathrm{NO}_{2}$ and 5 vol\% $\mathrm{H}_{2} \mathrm{O}$ ). The feed gases ( $\mathrm{N}_{2}, \mathrm{O}_{2}$ and 1040 ppmv $\mathrm{NO}_{2}$ in $\mathrm{N}_{2}$ - all from AGA A/S) were dosed by means of Bronkhorst EL-FLOW mass flow controllers. Distilled water was fed using a Knauer K-120 HPLC pump. When the sample had been installed in the oven, and once any remnants of air had been purged from the reactor (when the $\mathrm{CO}_{2}$ signal from ambient air had fallen below the detection limit) the reactor was heated at a rate of $11^{\circ} \mathrm{C} / \mathrm{min}$ to a final temperature of $750{ }^{\circ} \mathrm{C}$. The temperature was monitored by a type K thermoelement at the external surface of the quartz tube wall. The concentrations of $\mathrm{CO}$ and $\mathrm{CO}_{2}$ in the reactor effluent were monitored continuously using an $\mathrm{ABB}$ AO2020 IR gas analyzer calibrated using a certified $\mathrm{CO} / \mathrm{CO}_{2} / \mathrm{N}_{2}$ gas mixture from AGA A/S. When water was fed, the reactor effluent was passed through an ice cooled U-tube condenser to avoid that water interfered with the $\mathrm{CO} / \mathrm{CO}_{2}$ analysis. During the experiments with $\mathrm{NO}_{2}$ the levels of $\mathrm{CO}$ and 
$\mathrm{CO}_{2}$ in the effluent stream were in the $0-200 \mathrm{ppmv}$ range. The conversion of gaseous reactants due to the soot oxidation was thus relatively limited, and the dependence on the oxidant concentration was omitted in the kinetic analyses.

The soot used in the present experiments was a reference material from NIST: "SRM 2975 Diesel Particulate Matter" (from an Industrial Forklift). Various characterizations of this carbonaceous material can be found in the literature [19, 55-57].

\subsection{Kinetic analysis}

The results have been interpreted in terms of a simple, global kinetic model (assuming differential conditions in the gas phase), where catalytic and non-catalytic oxidation by $\mathrm{O}_{2}$ and $\mathrm{NO}_{2}$ are assumed to occur by 4 parallel reactions:

$$
\frac{d X}{d t}=k_{\mathrm{NO}_{2}, \text { cat }}(1-X)^{2 / 3}+k_{\mathrm{O}_{2}, \text { cat }}(1-X)^{2 / 3}+k_{\mathrm{NO}_{2}, \text { non-cat. }}(1-X)^{2 / 3}+k_{\mathrm{O}_{2}, \text { non-cat. }}(1-X)^{2 / 3}
$$

Here $X$ is the degree of carbon conversion, and $k$ is the rate constant for either catalytic or noncatalytic oxidation by either $\mathrm{O}_{2}$ or $\mathrm{NO}_{2}$. The degree of conversion is obtained from numerical integration of the $\mathrm{CO}$ and $\mathrm{CO}_{2}$ signals. The kinetic parameters for soot oxidation by $\mathrm{O}_{2}$ were taken from our previous study of oxidation in the absence of $\mathrm{NO}_{2}$ [20]. The kinetic parameters for noncatalytic oxidation by $\mathrm{NO}_{2}$ were determined in the absence of a catalyst, and the kinetic parameters for catalytic oxidation by $\mathrm{NO}_{2}$ are then fitted to the results from the present catalytic experiments. The obtained kinetic parameters are listed in table S2 in the supplementary information. The assumption of oxidation by $\mathrm{O}_{2}$ and $\mathrm{NO}_{2}$ as parallel reactions is supported by the results of Arthur et al. [49]. Across all the tested samples (both non-catalytic oxidation as well as loose and tight 
contact catalytic oxidation) the best fit for the simple kinetic model was achieved with a carbon reaction order of $2 / 3$. This is consistent with the soot particles behaving as uniformly shrinking spheres [58]. However, as discussed elsewhere [59], other situations may lead to similar reaction orders. An evaluation of the present results in terms of the temperature of maximal oxidation rate (the optimum between the increase in reaction rate with temperature and the decline in reaction rate with increasing reactant consumption), which is another common measure of activity in soot oxidation, generally yields the same conclusions, and such an analysis is provided in the supplementary information (figure S1).

\section{Results and Discussion}

\subsection{Soot oxidation in the presence of $\mathrm{NO}_{2}$}

Figure 1 shows the rate of soot oxidation in a gas atmosphere containing various combinations of $\mathrm{O}_{2}, \mathrm{NO}_{2}$ and $\mathrm{H}_{2} \mathrm{O}$ with and without the presence of a $\mathrm{Cr}_{2} \mathrm{O}_{3}$ catalyst $\left(17 \mathrm{~m}^{2} / \mathrm{g}\right)$ in loose contact with the soot. In agreement with previous work [46-50] the results show that the presence of $\mathrm{NO}_{2}$ significantly increases the soot oxidation rate in the $250-550^{\circ} \mathrm{C}$ range, although the temperature of the maximal oxidation rate for non-catalytic oxidation does not change significantly in the presence of $\mathrm{NO}_{2}$. The beneficial effect of $\mathrm{NO}_{2}$ could be related to the fact that the strength of the O-NO bond in $\mathrm{NO}_{2}$ is substantially weaker ( $D_{298 \mathrm{~K}}^{\circ}=305 \frac{\mathrm{kJ}}{\mathrm{mol}}$ ) than the strength of the O-O bond in $\mathrm{O}_{2}$ ( $D_{298 K}^{\circ}=498.36 \frac{\mathrm{kJ}}{\mathrm{mol}}$ ) [60]. Furthermore $\mathrm{NO}_{2}$ is also a radical species that decomposes to $\mathrm{NO}$ and $\mathrm{O}$ radicals with relative ease, especially in the presence of a catalytic surface [61-63]. It has also previously been proposed that the $\mathrm{NO}_{2}$ activation is by dissociation to yield atomic oxygen [49], which is known to react with graphite with a high probability [40]. 
Compared to oxidation with $\mathrm{O}_{2}$ alone, the presence of $\mathrm{NO}_{2}$ leads to an increased fraction of the carbon being released as $\mathrm{CO}_{2}$, particularly in the $250-550{ }^{\circ} \mathrm{C}$ range where oxidation by $\mathrm{NO}_{2}$ is most important, and this effect is further increased by the presence of water (supplementary information, figures S6-S8).

Figure 1 shows that at lower temperatures the $\mathrm{NO}_{2}$ assisted rate is further increased by the presence of water. The present observation of a doubling of the non-catalytic, $\mathrm{NO}_{2}$ assisted reaction rate at $300{ }^{\circ} \mathrm{C}$ by the addition of 5 vol\% $\mathrm{H}_{2} \mathrm{O}$ is in good agreement with other studies using similar concentrations of $\mathrm{NO}_{\mathrm{x}}$ and $\mathrm{H}_{2} \mathrm{O}[46,64,65]$. The beneficial effect of water requires the presence of $\mathrm{NO}_{\mathrm{x}}$, as the addition of water to the $\mathrm{O}_{2} / \mathrm{N}_{2}$ feed is without effect on the oxidation rate. It has previously been suggested $[41,65-68]$ that the effect of water and $\mathrm{NO}_{\mathrm{x}}$ is due to the impact of protonated species, particularly $\mathrm{HNO}_{3}$ and/or $\mathrm{OH}$-species formed by reactions between $\mathrm{H}_{2} \mathrm{O}$ and $\mathrm{NO}_{\mathrm{x}}$. Oxidation of carbon surfaces by $\mathrm{HNO}_{3}$ generates a significant fraction of acidic surface species that upon heating release significant fractions of $\mathrm{CO}_{2}$ and $\mathrm{H}_{2} \mathrm{O}$ at relatively low temperatures [69, 70]. Computational studies [71] have also suggested that $\mathrm{HNO}_{3}$ may create $\mathrm{OH}$ species on the surface of graphite, and the high reactivity of $\mathrm{OH}$ radicals in carbon oxidation has previously been established in several studies [72-75]. Attack on aromatic groups in the soot by nitric acid is also a possible mechanism.

The determined activation energies from the results in figure 1 for soot oxidation by $\mathrm{NO}_{2}(40$ $\mathrm{kJ} / \mathrm{mol})$ and $\mathrm{NO}_{2}+\mathrm{H}_{2} \mathrm{O}(25 \mathrm{~kJ} / \mathrm{mol})$ are considerably lower than for oxidation by $\mathrm{O}_{2}(198.5 \mathrm{~kJ} / \mathrm{mol})$. There are presumably several factors that contribute to the lower activation energy in the presence of $\mathrm{NO}_{2}$. Firstly, the presence of the more reactive oxidant is expected to raise the oxygen coverage on the surface of the carbonaceous material, and the activation energies for desorption of CO and $\mathrm{CO}_{2}$ from oxidized species in the surface of graphite are known to decrease with increasing oxygen coverage [76-80]. Secondly, treatment with $\mathrm{NO}_{2}$ or $\mathrm{HNO}_{3}$ creates a significant fraction of di- 
oxygenated carbon species in the surface of the carbonaceous material [69, 70, 81, 82], and the activation energy for desorption of $\mathrm{CO}_{2}$ from a di-oxygenated surface species is significantly lower than the activation energy for CO desorption from mono-oxygenated surface species [83, 84]. Thirdly, the decomposition of formed $\left[\mathrm{CONO}_{2}\right]$ surface complexes to $\mathrm{CO}_{2}$ and $\mathrm{NO}$ occurs at relatively low temperatures [82, 85], which is indicative of a low activation energy of desorption.

Figure 1 also shows that the oxidation by both $\mathrm{O}_{2}$ and $\mathrm{O}_{2}+\mathrm{NO}_{2}$ benefits from the presence of a catalyst even though the catalyst is only in loose contact (i.e. stirred together) with the soot. The catalytic oxidation is accelerated considerably by $\mathrm{NO}_{2}$ whereby the oxidation is shifted $\sim 100{ }^{\circ} \mathrm{C}$ down in temperature, a level of improvement that is quite general for all the studied catalysts (see supplementary information, figure S1). As discussed in the introduction a primary role of the catalyst in loose contact may well be to activate the oxidant, possibly by dissociative adsorption, to create adsorbed atomic oxygen, which can diffuse to reactive sites on the surface of the carbonaceous material and react. Such a mechanism would also be expected to benefit from the presence of the more reactive oxidant with weaker internal bonds, such as $\mathrm{NO}_{2}$. Another potentially beneficial role of a catalyst would be to re-oxidize NO, which has donated oxygen to carbon, back into $\mathrm{NO}_{2}$, whereby the $\mathrm{NO}_{2}$ level in the gas is maximized. The influence from catalytic re-oxidation of NO is, however, expected to be a minor effect in the present experiments, where $\mathrm{NO}_{2}$ is fed in substantial excess compared to the evolved amounts of $\mathrm{CO}_{\mathrm{x}}$.

\subsection{Catalytic oxidation in loose contact with a catalyst}

Figure 1 shows that loose contact with a catalyst can influence the oxidation significantly and that the catalytic oxidation is shifted to lower temperature by the presence of $\mathrm{NO}_{2}$. Figure 2 shows the 
rate of soot oxidation as a function of temperature both without a catalyst and in loose contact with $\mathrm{CeO}_{2}, \mathrm{Cr}_{2} \mathrm{O}_{3}$ or Pt as catalysts in a feed containing 10.2 vol\% $\mathrm{O}_{2}$ and $934 \mathrm{ppmv} \mathrm{NO}_{2}$. Figure 2 shows that the differences between the various catalysts are modest. However, it is clear that the oxidation benefits from the presence of a catalyst and that $\mathrm{Cr}_{2} \mathrm{O}_{3}$ is the most active of the catalysts evaluated in figure 2 - especially when considering the surface areas of the catalysts.

Assuming that the role of the catalyst is oxidant activation, and assuming that the number of sites contributing to the oxidant activation scales linearly with the total surface area of these bulk catalysts, it would seem reasonable to normalize the catalytic activity by the total surface area. Figure 3 shows, for various catalytic materials, the fitted rate constants at $550{ }^{\circ} \mathrm{C}$ for loose contact soot oxidation by $\mathrm{NO}_{2}+\mathrm{O}_{2}$ and $\mathrm{O}_{2}$ as a functions of their heats of oxygen chemisorption (a full list of kinetic parameters can be found in the supplementary information). Figure 3 indicates that the rate constants with approximation outline a so-called volcano curve with an optimal activity at intermediate bond strength. When comparing the results in figure 3 for oxidation by $\mathrm{O}_{2}$ and $\mathrm{O}_{2}+\mathrm{NO}_{2}$ it is first of all clear that a marked increase in oxidation rate is seen for all materials in the presence of $\mathrm{NO}_{2}$. The best fit might be suggest that the optimal bond strength is shifted slightly upwards $(\sim 3 \mathrm{~kJ} / \mathrm{mol})$ by the presence of $\mathrm{NO}_{2}$, but the number of data points does not allow a fully unambiguous conclusion on this point. Among the tested pure oxides $\mathrm{Cr}_{2} \mathrm{O}_{3}$ is still the most active material with both $\mathrm{O}_{2}$ and $\mathrm{O}_{2}+\mathrm{NO}_{2}$. In the case of $\mathrm{NH}_{3}$ synthesis changes in the gas atmosphere has been observed to shift the volcano curve by $10-20 \mathrm{~kJ} / \mathrm{mol}$ in bond strength [51, 52]. This is the same order of magnitude as the shift hinted by the soot oxidation data.

All catalysts show a markedly increased reaction rate in the presence of $\mathrm{NO}_{2}$ and in the catalytic soot oxidation the fraction of the carbon released as CO is generally low compared to non-catalytic soot oxidation (supplementary information, figure S9). It is difficult to establish to which extent this occurs because more of the immediate oxidation product is $\mathrm{CO}_{2}$ or because $\mathrm{CO}$ from the soot 
oxidation is subsequently oxidized to $\mathrm{CO}_{2}$ over the catalyst. It is known that oxygen spillover from the catalyst raises the oxygen coverage on the soot [35], and this is likely to create more dioxygenated species on the carbonaceous surface that could decompose to $\mathrm{CO}_{2}$. So it is not unlikely that in the presence of a catalyst there is more $\mathrm{CO}_{2}$ in the immediate product of the soot oxidation.

With approximation the determined activation energies for loose contact soot oxidation by $\mathrm{NO}_{2}$ depend linearly on the heat of oxygen chemisorption (supplementary information figure S10) - a so-called Brønsted-Evans-Polanyi relationship [86, 87], but the tendency appears uncertain for materials binding oxygen more strongly than $\mathrm{Fe}_{2} \mathrm{O}_{3}$.

As previously mentioned another potential role of the catalyst in connection with the $\mathrm{NO}_{2}{ }^{-}$ assisted soot oxidation is to reoxidize $\mathrm{NO}$, which has relinquished oxygen to soot, back into $\mathrm{NO}_{2}$. The noble metals are known to be very active for the NO oxidation [44-46]. Additionally, the activity for NO oxidation is expected to benefit from a decreasing oxygen bond strength on the catalyst, as for example $\mathrm{Co}_{3} \mathrm{O}_{4}$, which binds oxygen relatively weakly [88, 89], exhibits a significant activity in this reaction [90].

\subsection{Effect of gas phase components on loose contact oxidation}

Both with and without $\mathrm{NO}_{2}$ in the gas the optimum of the activity volcano appears to be located between the binding energies of $\mathrm{Cr}_{2} \mathrm{O}_{3}$ and $\mathrm{Fe}_{2} \mathrm{O}_{3}$ (figure 3). Guided by a classic interpolation principle [91] we have previously [20] tested a range of silica supported $\mathrm{Fe}_{\mathrm{a}} \mathrm{Cr}_{\mathrm{b}} \mathrm{O}_{\mathrm{x}}$ binary oxides and found that activity passed through an optimum for a $\mathrm{FeCr}_{2} \mathrm{O}_{\mathrm{x}}$ catalyst. It is also relevant to test how this optimized catalyst depends on the reaction conditions. Figure 4 shows the rate of soot oxidation in loose contact with $\mathrm{FeCr}_{2} \mathrm{O}_{\mathrm{x}} / \mathrm{SiO}_{2}$ as a function of temperature in gas atmospheres containing various combinations of $\mathrm{O}_{2}, \mathrm{NO}_{2}$ and $\mathrm{H}_{2} \mathrm{O}$. 
Figure 4 shows that it is possible to shift the oxidation to a significantly lower temperature by having an $\mathrm{NO}_{2}$ containing gas atmosphere and using an $\mathrm{FeCr}_{2} \mathrm{O}_{\mathrm{x}} / \mathrm{SiO}_{2}$ catalyst even with only loose soot/catalyst contact. The promotional effect of water on the oxidation by $\mathrm{NO}_{2}$, which was observed in non-catalytic oxidation (figure 1), is relatively less pronounced in the presence of a catalyst (figure 4) and is mainly visible by the oxidation finishing at a $\sim 50{ }^{\circ} \mathrm{C}$ lower temperature in the presence of $\mathrm{H}_{2} \mathrm{O}$. Generally the rate of the catalytic oxidation exhibits the same dependence on the atmosphere as the non-catalytic oxidation.

It is worth emphasizing that a more reactive atmosphere and the use of a catalyst, even in loose contact with the soot, can shift the oxidation temperature towards significantly lower temperatures. Figure 4 shows for example how it with $\mathrm{H}_{2} \mathrm{O}+\mathrm{NO}_{2}+\mathrm{O}_{2}$ and the $\mathrm{FeCr}_{2} \mathrm{O}_{\mathrm{x}} / \mathrm{SiO}_{2}$ catalyst is possible to reach the same oxidation rate at $275-300{ }^{\circ} \mathrm{C}$ that non-catalytic oxidation by only $\mathrm{O}_{2}$ does not reach until $\sim 550^{\circ} \mathrm{C}$. This is even under conditions where effects from the heat of reaction is sought to be minimized by small sample amounts and high flows ( $\Sigma \mathrm{CO}_{\mathrm{x}}$ always below $\left.372 \mathrm{ppmv}\right)$. That such a major downshift in oxidation temperature can be achieved under such conditions, also in loose contact, illustrates the potential improvements that may be achieved by a systematic optimization of catalyst and process conditions.

\subsection{Catalytic oxidation in tight contact with a catalyst}

In tight contact oxidation tests soot and catalyst are crushed together and an extensive interface between soot and catalyst is formed [10]. In tight contact with an active catalyst the rate is already at low temperatures considerably faster than in any of the oxidation tests shown in figure 1 [20]. As 
discussed in the introduction the tight contact oxidation most likely occurs via the Mars van Krevelen mechanism, whereby terminal lattice oxygen from the catalyst is transferred to carbon followed by a re-oxidation of the resulting oxygen vacancy in the catalyst surface by an oxidant from the gas phase. The most active catalysts for this contact type are those that bind their surface oxygen weakly - such as $\mathrm{Co}_{3} \mathrm{O}_{4}$ and $\mathrm{CeO}_{2}[20]$.

Figure 5 shows that the gas atmosphere only has a very limited impact on the soot oxidation in tight contact with $\mathrm{Co}_{3} \mathrm{O}_{4}$. Addition of $887 \mathrm{ppmv} \mathrm{NO}_{2}$ and 5.0 vol\% $\mathrm{H}_{2} \mathrm{O}$ to 10 vol\% $\mathrm{O}_{2} / \mathrm{N}_{2}$ only results in a slightly higher activity at the temperature of maximal oxidation rate (this could be related to a contribution from the non-catalytic oxidation by $\mathrm{NO}_{2}$ ), but the differences are modest, and the temperature range wherein the oxidation occurs is almost completely identical in the presence or absence of $\mathrm{NO}_{2}+\mathrm{H}_{2} \mathrm{O}$. For a Mars van Krevelen mechanism, where reaction between carbon and lattice oxygen rather than catalyst re-oxidation is rate limiting, the presence of a more reactive oxidant in the gas will not necessarily increase the reaction rate, since the re-oxidation of the catalyst is only a minor limitation on the rate. Theoretical studies [92] for $\mathrm{Co}_{3} \mathrm{O}_{4}(110)$ indicate that oxygen vacancy re-occupation by $\mathrm{O}_{2}$ is barrierless, so it seems very likely that the oxide reoxidation is facile even on weakly binding $\mathrm{Co}_{3} \mathrm{O}_{4}$. The limited effect of a more reactive atmosphere observed in the tight contact with $\mathrm{Co}_{3} \mathrm{O}_{4}$ can thus be rationalized in terms of the expected reaction mechanism. Consequently there is in tight contact oxidation not necessarily a significant gain from the presence of a more reactive gas atmosphere, unless the studied catalyst is significantly limited by the oxygen activation during the re-oxidation of the catalyst. If the conditions become more oxygen deficient the re-oxidation will of course eventually become rate limiting, and a dependence on the oxidant concentration will emerge. There may also be some catalytic materials (particularly weakly-binding surfaces such as gold $[20,63])$ that will benefit from a more reactive oxidant raising 
the oxygen coverage on the catalyst. However, the highly active $\mathrm{Co}_{3} \mathrm{O}_{4}$ catalyst investigated here appears to have reached the 0 . order regime, where the rate is independent of oxidant concentration.

\section{Conclusion}

The rate of non-catalytic soot oxidation in a $10 \mathrm{vol} \% \mathrm{O}_{2}$ in $\mathrm{N}_{2}$ atmosphere is significantly increased by addition of 934 ppmv $\mathrm{NO}_{2}$ to the gas. The weaker $\mathrm{O}-\mathrm{NO}$ bond in $\mathrm{NO}_{2}$ than the $\mathrm{O}-\mathrm{O}$ bond in $\mathrm{O}_{2}$ and the radical nature of $\mathrm{NO}_{2}$ are possible reasons for the higher reactivity. At lower temperatures the $\mathrm{NO}_{2}$-assisted oxidation rate is further increased by the addition of water to the gas, and 5 vol\% $\mathrm{H}_{2} \mathrm{O}$ causes a doubling of the $\mathrm{NO}_{2}$-assisted rate at $300{ }^{\circ} \mathrm{C}$. The beneficial effect of water may be related to the involvement of protonated species such as $\mathrm{HNO}_{3} . \mathrm{HNO}_{3}$ generates acidic surface sites on the carbonaceous material that can decompose to $\mathrm{CO}_{2}$ at relatively low temperatures. The beneficial effect of water requires the presence of $\mathrm{NO}_{2}$, as the addition of 5 vol\% water to an $\mathrm{O}_{2} / \mathrm{N}_{2}$ gas mixture does not affect the rate significantly. The oxidation temperature can be lowered further by the use of a catalyst. If the soot is in loose contact with a catalyst (with the materials stirred together) the impact of the gas composition is similar to the non-catalytic case, namely with a significant acceleration of the oxidation rate by $\mathrm{NO}_{2}$ (oxidation temperature lowered $\sim 100{ }^{\circ} \mathrm{C}$ by 934 ppmv $\mathrm{NO}_{2}$ ) and possibly a smaller additional enhancement by $\mathrm{H}_{2} \mathrm{O}$. For a number of catalytic materials the rate constants for loose contact soot oxidation by $\mathrm{NO}_{2}$ outline a volcano curve as a function of their heats of oxygen chemisorption (as a measure of the oxygen bond strength on the catalyst). The location of the optimum of the volcano curve is very close to the position of the optimum for oxidation by $\mathrm{O}_{2}$, and among the investigated pure oxides and metals $\mathrm{Cr}_{2} \mathrm{O}_{3}$ was nearest to the optimal bond strength. If the soot is in tight contact with a catalyst (soot and catalyst crushed together) the catalytic oxidation is considerably faster than the non-catalytic oxidation (with or 
without $\mathrm{NO}_{2}$ ), and with $\mathrm{Co}_{3} \mathrm{O}_{4}$, which is a good tight contact catalyst, the reaction rate does not benefit significantly from the addition of $\mathrm{NO}_{2}+\mathrm{H}_{2} \mathrm{O}$ to the $\mathrm{O}_{2} / \mathrm{N}_{2}$ atmosphere. This agrees with the mechanism of tight contact oxidation being of the Mars-van Krevelen type, and where the transfer of lattice oxygen to the soot is rate limiting

\section{Appendix A. Supplementary material}

Evaluation of activity in terms of $\mathrm{T}_{\max }$-values. Kinetic parameters and examples of fits to data. Analysis of the effect of $\mathrm{NO}_{2}$ on the $\mathrm{CO} / \mathrm{CO}_{2}$ distribution in effluent gas. Brønsted-Evans-Polanyi relationship for soot oxidation by $\mathrm{NO}_{2}$.

\section{Acknowledgements}

Financial support from The Danish Council for Strategic Research (Grant No. 2106-08-0039) and from the Innovation Fund Denmark (Grant No. 103-2012-3) is gratefully acknowledged.

\section{References}

[1] C. Ris, Inhal. Toxicol. 19 (2007) 229-239.

[2] B. Frank, M. Schuster, R. Schlögl, D.S. Su, Angew. Chem. Int. Ed. 52 (2013) 2673-2677.

[3] D.B. Kittelson, J. Aerosol Sci. 29 (1998) 575-588.

[4] B.A.A.L. Van Setten, M. Makkee, J.A. Moulijn, Catal. Rev. Sci. Eng. 43 (2001) 489-564.

[5] J. Neeft, M. Makkee, J.A. Moulijn, Fuel. Process. Technol. 47 (1996) 1-69.

[6] J. Adler, Int. J. Appl. Ceram. Technol. 2 (2005) 429-439.

[7] A.M. Stamatelos, Energy Convs. Mgmt. 38 (1997) 83-99.

[8] J. Neeft, M. Makkee, J.A. Moulijn, Chem. Eng. J. 64 (1996) 295-302. 
[9] J. Neeft, M. Makkee, J.A. Moulijn, Appl. Catal. B 8 (1996) 57-78.

[10] D. Gardini, J.M. Christensen, C.D. Damsgaard, A.D. Jensen, J.B. Wagner, Appl. Catal. B 183 (2016) 28-36.

[11] A.G. Konstandopoulos, S. Lorentzou, C. Pagkoura, K. Ohno, K. Ogyu, T. Oya, SAE paper 2007-01-1950, 2007.

[12] A.G. Konstandopoulos, E. Papaioannou, Kona 26 (2008) 36-65.

[13] A. Konstandopolous, E. Papaioannou, D. Zarvalis, S. Skopa, P. Baltzopoulou, E. Kladopoulou, M. Kostoglou, S. Lorentzou, SAE paper 2005-01-0670, 2005.

[14] P.A. Kumar, M.D. Tanwar, S. Bensaid, N. Russo, D. Fino, Chem. Eng. J. 207-208 (2012) 258266.

[15] B.W.L. Southward, S. Basso, SAE paper 2008-01-0481, 2008.

[16] V. Di Sarli, G. Landi, L. Lisi, A. Saliva, A. Di Benedetto, Appl. Catal. B 197 (2016) 116-124.

[17] V.R. Pérez, A. Bueno-López, Chem. Eng. J. 279 (2015) 79-85.

[18] Q. Liang, X. Wu, X. Wu, D. Weng, Catal. Lett. 119 (2007) 265-270.

[19] J.M. Christensen, D. Deiana, J.-D. Grunwaldt, A.D. Jensen, Catal. Lett 144 (2014) 1661-1666.

[20] J.M. Christensen, J.-D. Grunwaldt, A.D. Jensen, Appl. Catal. B 188 (2016) 235-244.

[21] E. Aneggi, N.J. Divins, C. de Leitenburg, J. Llorca, A. Trovarelli, J. Catal. 312 (2014) 191194.

[22] S. Simonsen, S. Dahl, E. Johnson, S. Helveg, J. Catal. 255 (2008) 1-5.

[23] M. Machida, Y. Murata, K. Kishikawa, D. Zhang, K. Ikeue, Chem. Mater. 20 (2008) 44894494.

[24] A. Bueno-Lopez, K. Krishna, M. Makkee, J. Moulijn, J. Catal. 230 (2005) 237-248.

[25] A. Bueno-López, K. Krishna, M. Makkee, J.A. Moulijn, Catal. Lett. 99 (2005) 203-205.

[26] G. Mul, F. Kapteijn, C. Doornkamp, J.A. Moulijn, J. Catal. 179 (1998) 258-266. 
[27] K. Harada, T. Oishi, S. Hamamoto, T. Ishihara, J. Phys. Chem. C 118 (2013) 559-568.

[28] S. Wagloehner, J.N. Baer, S. Kureti, Appl. Catal. B 147 (2014) 1000-1008.

[29] L. Soler, A. Casanovas, C. Escudero, V. Pérez-Dieste, E. Aneggi, A. Trovarelli, J. Llorca, ChemCatChem 8 (2016) 2748-2751.

[30] P. Mars, D.W. Van Krevelen, Chem. Eng. Sci. Special Suppl. 3 (1954) 41-59.

[31] K. Suzuki, K. Harada, H. Yamada, K. Okamoto, A. Takami, SAE paper 2007-01-1919, 2007.

[32] K. Yamazaki, Y. Sakakibara, F. Dong, H. Shinjoh, Appl. Catal. A 476 (2014) 113-120.

[33] D. Reichert, H. Bockhorn, S. Kureti, Appl. Catal. B 80 (2008) 248-259.

[34] S. Wagloehner, M. Nitzer-Noski, S. Kureti, Chem. Eng. J. 259 (2015) 492-504.

[35] G. Mul, J.P.A. Neeft, F. Kapteijn, J.A. Moulijn, Carbon 36 (1998) 1269-1276.

[36] L. Zeng, T. Turek, A.P. Weber, Chem. Ing. Tech. 83 (2011) 1276-1281.

[37] L. Zeng, A.P. Weber, Chem. Ing. Tech. 84 (2012) 295-300.

[38] R.T.K. Baker, J.J. Chludzinski, Carbon 19 (1981) 75-82.

[39] D.W. McKee, Carbon 8 (1970) 623-635.

[40] H.D. Allendorf, D.E. Rosner, AIAA J. 6 (1968) 650-654.

[41] J. Oi Uchisawa, A. Obuchi, Z. Zhao, S. Kushiyama, Appl. Catal. B 18 (1998) L183-L187.

[42] J. Oi-Uchisawa, A. Obuchi, A. Ogata, R. Enomoto, S. Kushiyama, Appl. Catal. B 21 (1999) 917.

[43] S. Liu, A. Obuchi, J. Uchisawa, T. Nanba, S. Kushiyama, Appl. Catal. B 37 (2002) 309-319.

[44] B.J. Cooper, H.J. Jung and J.E. Thoss, Eur. Patent 0341832 (1996), to Johnson Matthey Inc. [45] W. Wang, G. McCool, N. Kapur, G. Yuan, B. Shan, M. Nguyen, U.M. Graham, B.H. Davis, G. Jacobs, K. Cho, X. Hao, Science 337 (2012) 832-835.

[46] B.J. Cooper, J.E. Thoss, SAE Paper 890404, 1989.

[47] J.-O. Müller, B. Frank, R.E. Jentoft, R. Schlögl, D.S. Su, Catal. Today 191 (2012) 106-111. 
[48] K.-Y. Choi, N.W. Cant, D.L. Trimm, J. Chem. Technol. Biotechnol. 71 (1998) 57-60.

[49] J.R. Arthur, H.F. Ferguson, K. Lauber, Nature 178 (1956) 206-207.

[50] X. Chu, L.D. Schmidt, Ind Eng Chem Res 32 (1993) 1359-1366.

[51] J.K. Nørskov, T. Bligaard, J. Rossmeisl, C.H. Christensen, Nature Chem. 1 (2009) 37-46.

[52] C.J.H. Jacobsen, S. Dahl, A. Boisen, B.S. Clausen, H. Topsøe, A. Logadottir, J.K. Nørskov, J. Catal. 205 (2002) 382-387.

[53] V. Di Sarli, A. Di Benedetto, Chem. Eng. Sci. 137 (2015) 69-78.

[54] V. Di Sarli, A. Di Benedetto, Ind. Eng. Chem. Res. 55 (2016) 11052-11061.

[55] J. Im, C.M. Lee, J.T. Coates, Chemosphere 71 (2008) 621-628.

[56] A. Braun, B.S. Mun, F.E. Huggins, G.P. Huffman, Environ. Sci. Technol. 41 (2007) 173-178.

[57] Ö. Gustafsson, T.D. Bucheli, Z. Kukulska, M. Andersson, C. Largeau, J.-N. Rouzaud, C.M.

Reddy, T.I. Eglinton, Global Biogeochem. Cycles 15 (2001) 881-890.

[58] O. Levenspiel, The chemical reactor omnibook, OSU Book Stores, Corvallis, Oregon, 1996.

[59] C.J. Tighe, M.V. Twigg, A.N. Hayhurst, J.S. Dennis, Combust. Flame 159 (2012) 77-90.

[60] D.R. Lide (Ed.), Handbook of Chemistry and Physics, 78th ed., CRC Press, USA, 1997.

[61] C. Decarne, E. Abi-Aad, A. Aboukaïs, Catal. Lett. 62 (1999) 45-48.

[62] D. Dahlgren, J.C. Hemminger, Surf. Sci. Lett. 123 (1982) L739-L742.

[63] X. Deng, B.K. Min, A. Guloy, C.M. Friend, J. Am. Chem. Soc. 127 (2005) 9267-9270.

[64] F. Jacquot, V. Logie, J.F. Brilhac, P. Gilot, Carbon 40 (2002) 335-343.

[65] M. Jeguirim, V. Tschamber, J.F. Brilhac, P. Ehrburger, Fuel 84 (2005) 1949-1956.

[66] K. Tikhomirov, O. Kröcher, M. Elsener, A. Wokaun, Appl. Catal. B 64 (2006) 72-78.

[67] D.H. Cotton, N.J. Friswell, D.R. Jenkins, Combust. Flame 17 (1971) 87-98.

[68] P. Glarborg, Proc. Comb. Inst. 31 (2007) 77-98.

[69] S.R. Kelemen, H. Freund, Energy Fuels 2 (1988) 111-118. 
[70] Y. Otake, R.G. Jenkins, Carbon 31 (1993) 109-121.

[71] A. Rodríguez-Fortea, M. Iannuzzi, M. Parrinello, J. Phys. Chem. B 110 (2006) 3477-3484.

[72] C.P. Fenimore, G.W. Jones, J. Phys. Chem. 71 (1967) 593-597.

[73] R.C. Millikan, J. Phys. Chem. 66 (1962) 794-799.

[74] B.S. Haynes, H.G. Wagner, Prog. Energy Combust. Sci. 7 (1981) 229-273.

[75] M.F.R. Mulcahy, B.C. Young, Carbon 13 (1975) 115-124.

[76] S.S. Barton, B.H. Harrison, J. Dollimore, J. Chem. Soc. , Faraday Trans. 169 (1973) 10391048.

[77] S.S. Barton, B.H. Harrison, J. Dollimore, J. Phys. Chem. 82 (1978) 290-294.

[78] S.R. Kelemen, H. Freund, Carbon 23 (1985) 619-625.

[79] Z.H. Zhu, J. Finnerty, G.Q. Lu, R.T. Yang, Energy Fuels 16 (2002) 1359-1368.

[80] P.L. Walker, R.L. Taylor, J.M. Ranish, Carbon 29 (1991) 411-421.

[81] A. Setiabudi, M. Makkee, J.A. Moulijn, Appl. Catal. B 50 (2004) 185-194.

[82] B. Azambre, S. Collura, J.M. Trichard, J.V. Weber, Appl. Surf. Sci. 253 (2006) 2296-2303.

[83] B. Marchon, J. Carrazza, H. Heinemann, G.A. Somorjai, Carbon 26 (1988) 507-514.

[84] B. Marchon, W.T. Tysoe, J. Carrazza, H. Heinemann, G.A. Somorjai, J. Phys. Chem. 92 (1988) 5744-5749.

[85] H. Muckenhuber, H. Grothe, Carbon 44 (2006) 546-559.

[86] M.G. Evans, M. Polanyi, Trans. Faraday Soc. 34 (1938) 11-24.

[87] J.N. Brønsted, K. Pedersen, Z. Phys. Chem. 108 (1924) 185-235.

[88] G.K. Boreskov, V.V. Popovsky,V.A. Sazonov, Fourth Int. Cong. Catal. - Reprints of Papers 2 (1968) 580-603. 
[89] V.A. Razdobarov, V.A. Sadykov, S.A. Veniaminov, N.N. Bulgakov, O.N. Kovalenko, Y.D. Pankratiev, V.V. Popovskii, G.N. Kryukova, S.F. Tikhov, React. Kinet. Catal. Lett. 37 (1988) 109114.

[90] B.M. Weiss, N. Artioli, E. Iglesia, ChemCatChem 4 (2012) 1397-1404.

[91] A.A. Balandin, Adv. Catal. 19 (1969) 1-210.

[92] D. Jiang, S. Dai, Phys. Chem. Chem. Phys 13 (2011) 978-984. 
Figure 1 The rate of soot oxidation (normalized by the total, initial amount of carbon) as a function of the temperature in various gas atmospheres and with and without the presence of a $\mathrm{Cr}_{2} \mathrm{O}_{3}$ catalyst (in loose contact). Experimental conditions: Soot:Catalyst $=1: 5 \mathrm{wt}: \mathrm{wt}, \mathrm{ramp}=11^{\circ} \mathrm{C} / \mathrm{min}, 1$ $\mathrm{NL} / \mathrm{min}$. Feed compositions: 10.2 vol\% $\mathrm{O}_{2}$ in $\mathrm{N}_{2} ; 9.7$ vol\% $\mathrm{O}_{2}$ and 5.0 vol\% $\mathrm{H}_{2} \mathrm{O}$ in $\mathrm{N}_{2} ; 10.2$ vol\% $\mathrm{O}_{2}$ and 934 ppmv $\mathrm{NO}_{2}$ in $\mathrm{N}_{2} ; 9.7$ vol\% $\mathrm{O}_{2}$, 887 ppmv $\mathrm{NO}_{2}$ and 5.0 vol\% $\mathrm{H}_{2} \mathrm{O}$ in $\mathrm{N}_{2}$.

Figure 2 The rate of soot oxidation (normalized by the total, initial mass of carbon) as a function of temperature in loose contact with $\mathrm{Pt}\left(32 \mathrm{~m}^{2} / \mathrm{g}\right), \mathrm{CeO}_{2}\left(182 \mathrm{~m}^{2} / \mathrm{g}\right)$ or $\mathrm{Cr}_{2} \mathrm{O}_{3}\left(17 \mathrm{~m}^{2} / \mathrm{g}\right)$. Experimental conditions: Soot:Catalyst $=1: 5 \mathrm{wt}: \mathrm{wt}$, ramp $=11^{\circ} \mathrm{C} / \mathrm{min}, 1 \mathrm{NL} / \mathrm{min}, 934 \mathrm{ppmv} \mathrm{NO}_{2}$ and $10.2 \mathrm{vol} \%$ $\mathrm{O}_{2}$ in $\mathrm{N}_{2}$.

Figure 3 The rate constant at $550{ }^{\circ} \mathrm{C}$ for soot oxidation in loose contact with a catalyst in an $\mathrm{O}_{2}+\mathrm{NO}_{2}\left(k_{\mathrm{O}_{2}}+k_{\mathrm{NO}_{2}}\right.$, filed points) or $\mathrm{O}_{2}\left(k_{\mathrm{O}_{2}}\right.$, open points) atmosphere as function of the heat of oxygen chemisorption for various catalytic materials. The rate constant is normalized by the surface area of the catalyst. Dashed lines given as a guide to the eye. The experimental conditions are given in connection with figure 2. The heats of oxygen chemisorption are taken from ref. [20].

Figure 4 The rate of soot oxidation (normalized by the total, initial amount of carbon) in loose contact with a $\mathrm{FeCr}_{2} \mathrm{O}_{\mathrm{x}} / \mathrm{SiO}_{2}$ catalyst a function of the temperature in various gas atmospheres. Experimental conditions: Soot:Catalyst $=1: 10 \mathrm{wt}: \mathrm{wt}$, ramp $=11^{\circ} \mathrm{C} / \mathrm{min}, 1 \mathrm{NL} / \mathrm{min}$. Feed compositions: 10.2 vol\% $\mathrm{O}_{2}$ in $\mathrm{N}_{2} ; 9.7$ vol\% $\mathrm{O}_{2}$ and 5.0 vol\% $\mathrm{H}_{2} \mathrm{O}$ in $\mathrm{N}_{2} ; 10.2$ vol\% $\mathrm{O}_{2}$ and 934 ppmv $\mathrm{NO}_{2}$ in $\mathrm{N}_{2} ; 9.7$ vol\% $\mathrm{O}_{2}$, 887 ppmv $\mathrm{NO}_{2}$ and 5.0 vol\% $\mathrm{H}_{2} \mathrm{O}$ in $\mathrm{N}_{2}$. 
Figure 5 The rate of soot oxidation (normalized by the total, initial mass of carbon) as a function of temperature in tight contact with the $\mathrm{Co}_{3} \mathrm{O}_{4}$ catalyst $\left(131 \mathrm{~m}^{2} / \mathrm{g}\right)$ in either $10.2 \mathrm{vol} \% \mathrm{O}_{2}$ in $\mathrm{N}_{2}$ or 9.7 vol\% $\mathrm{O}_{2}, 887$ ppmv $\mathrm{NO}_{2}$ and 5.0 vol\% $\mathrm{H}_{2} \mathrm{O}$ in $\mathrm{N}_{2}$. Experimental conditions: Soot:Catalyst $=1: 5$ wt:wt, ramp $=11^{\circ} \mathrm{C} / \mathrm{min}, 1 \mathrm{NL} / \mathrm{min}$. 


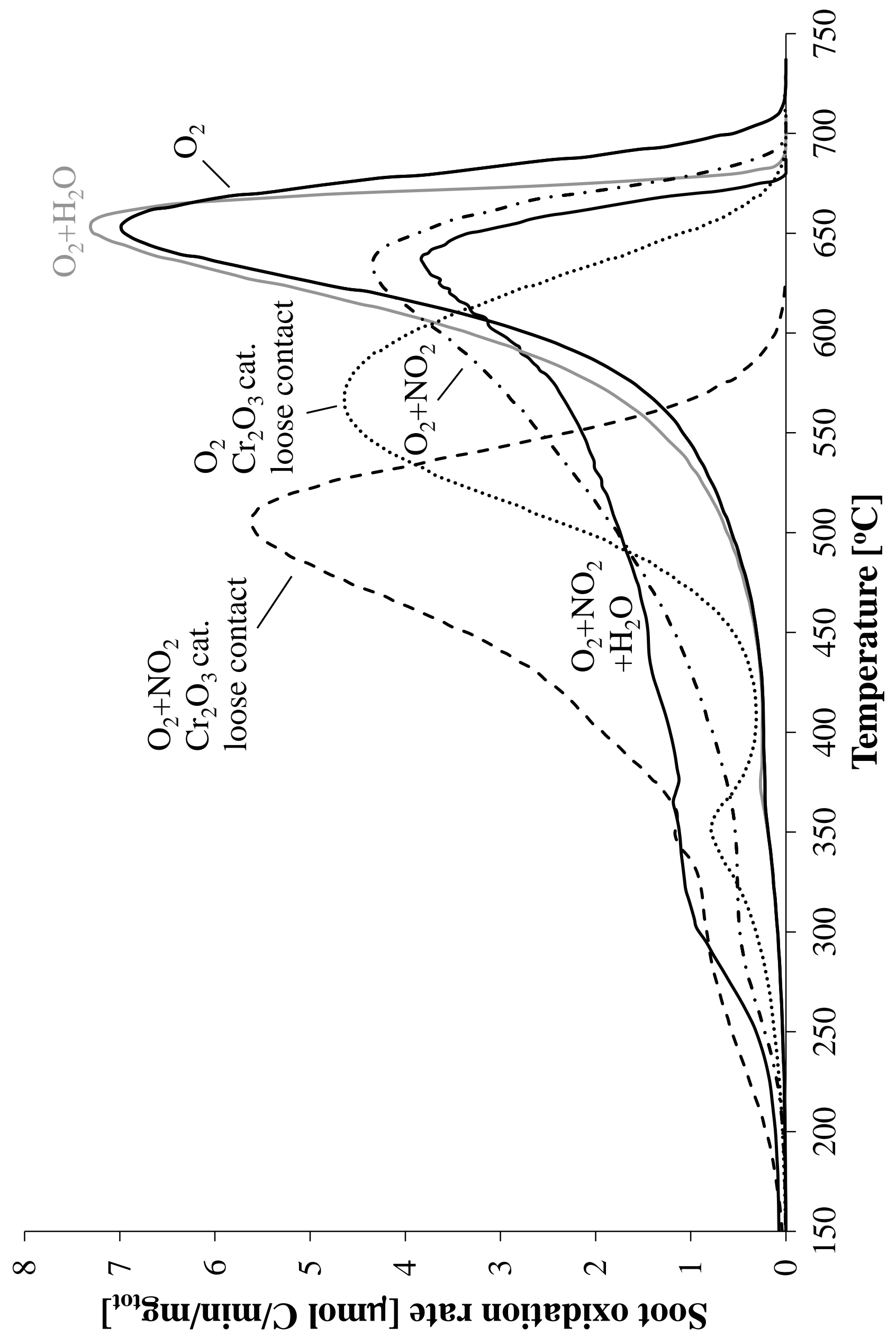

궁 


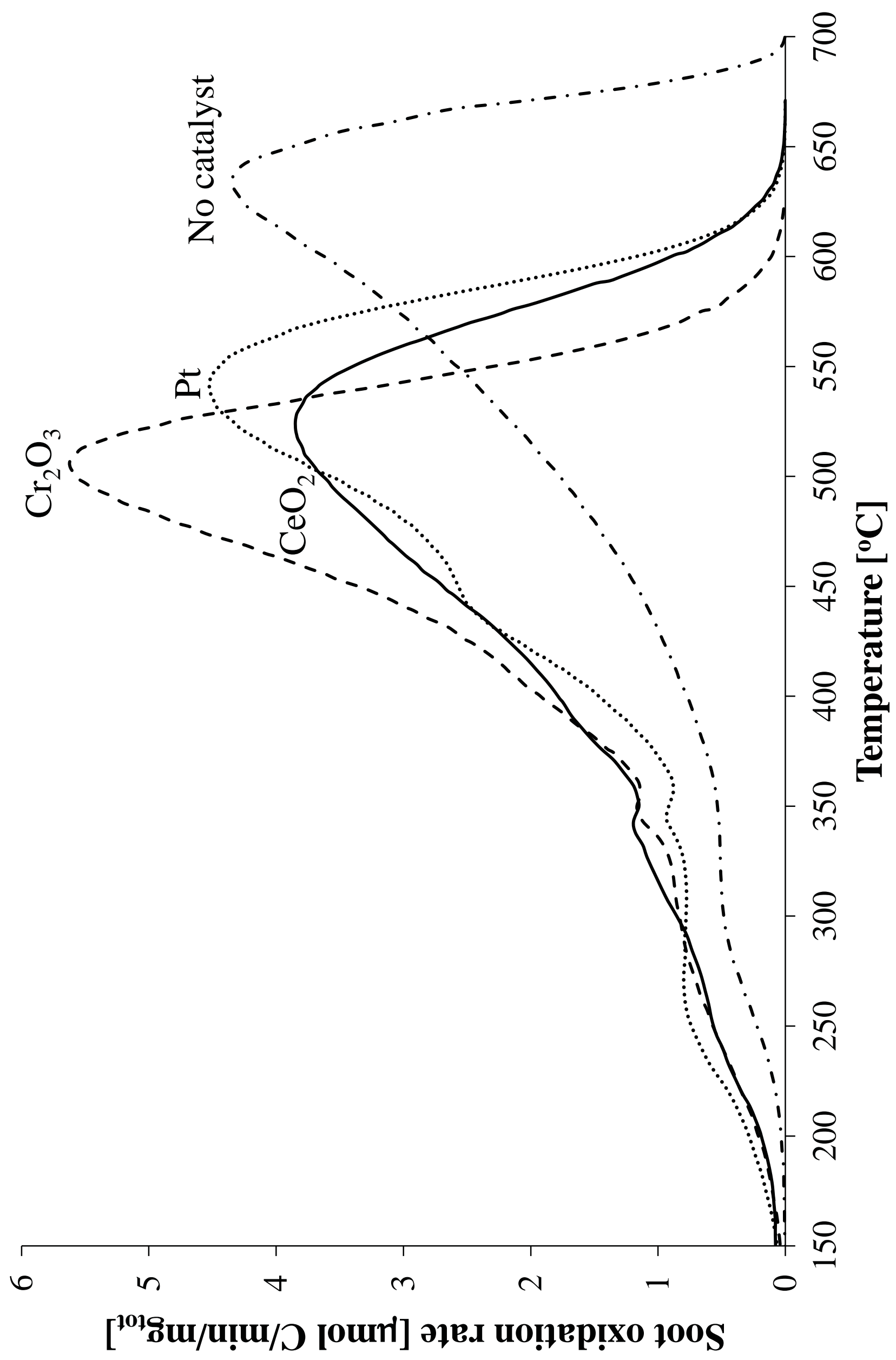




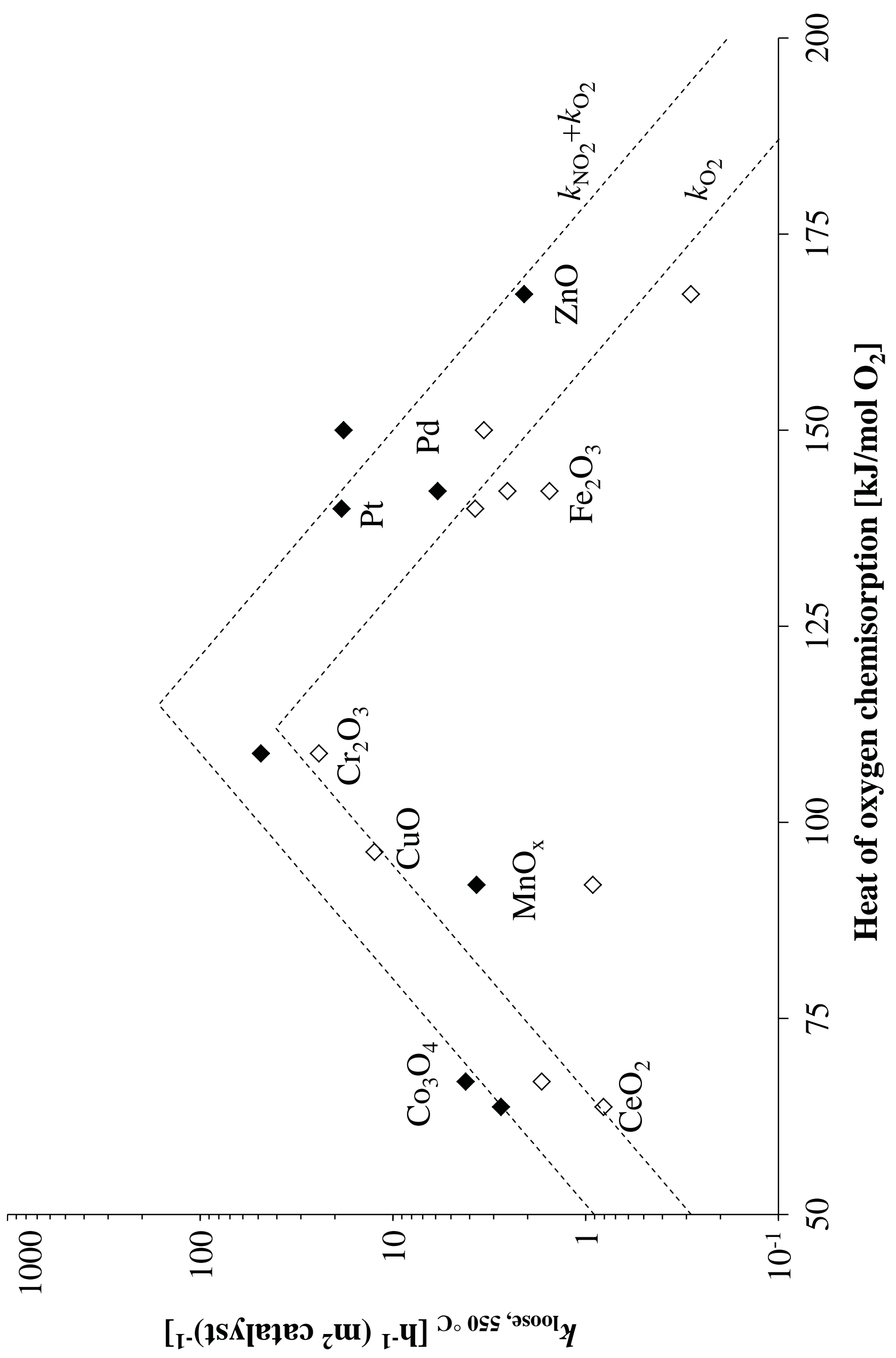

m 


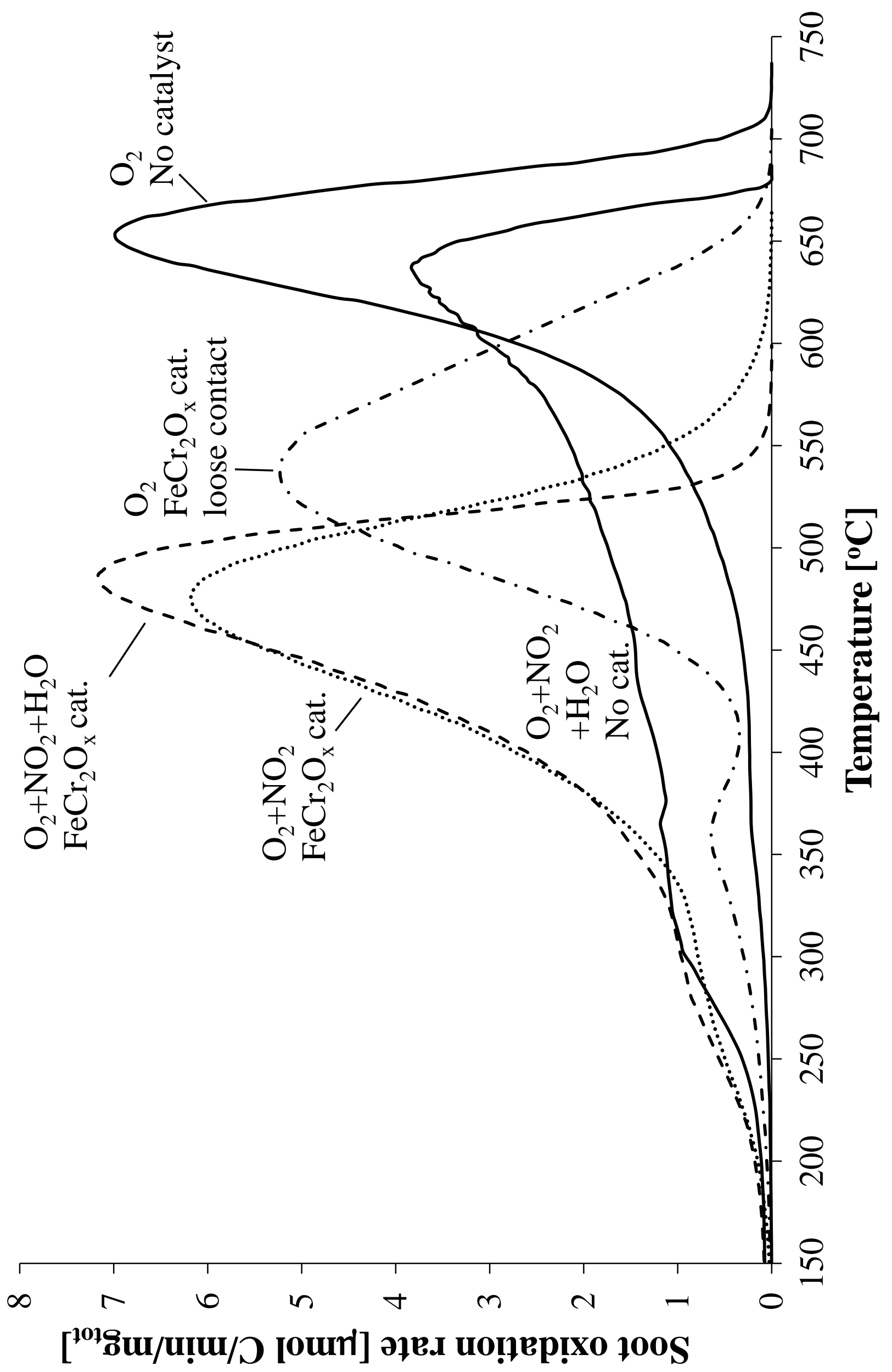

㐫 


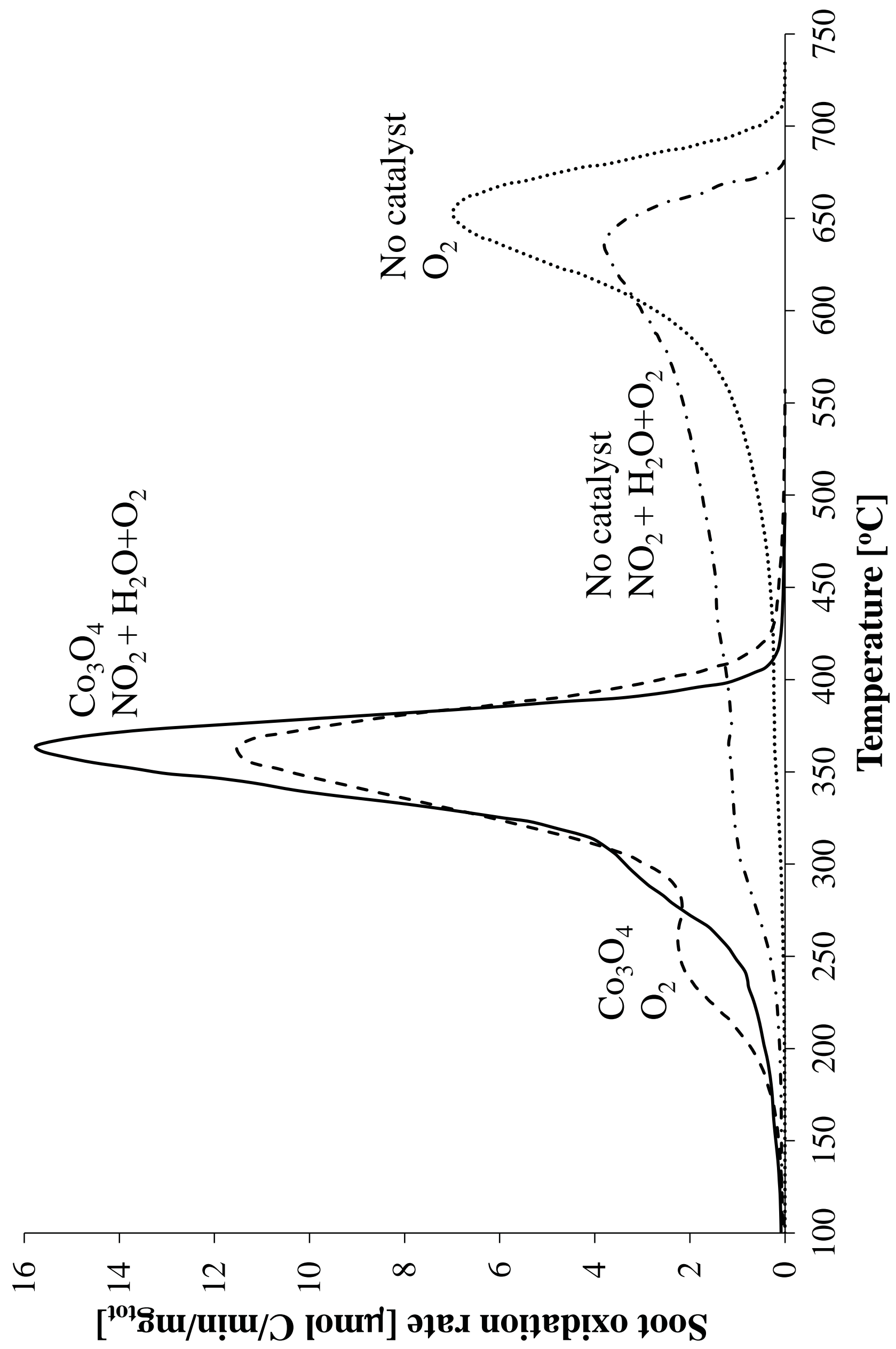

온 
Highlights

- Oxidation of soot in loose contact with a catalyst is significantly enhanced by $\mathrm{NO}_{2}$

- Loose contact oxidation by $\mathrm{NO}_{2}$ has a volcano-type dependence on bond strength of oxygen on the surface

- Addition of $\mathrm{NO}_{2}$ and loose contact with $\mathrm{FeCr}_{2} \mathrm{O}_{x}$ shifts oxidation down by $\geq 200{ }^{\circ} \mathrm{C}$

- For soot in tight contact with a $\mathrm{CO}_{3} \mathrm{O}_{4}$ catalyst hardly any effect of $\mathrm{NO}_{2}$

- Limited effect on oxidation in tight contact consistent with Mars van Krevelen mechanism 